\title{
The role of rectal chloride secretion in childhood constipation
}

\author{
N. BEKKAli, ${ }^{\star}$ H. R. DE JONGE, $\dagger$ R. M. J. G. J. VAN DEN WIJNGAARD, $\ddagger$ A. F. W. VAN DER STEEG, $९$ P. B. BIJLSMA, ${ }^{\star}$ \\ J. A. J. M. TAMINIAU, ${ }^{\star}$ J. F. DESJEUX \& M. A. BENNINGA * \\ ${ }^{\star}$ Department of Paediatric Gastroenterology and Nutrition, Emma Children's Hospital, Amsterdam, The Netherlands \\ $\dagger$ Department of Biochemistry, Erasmus University Medical Centre, Rotterdam, The Netherlands \\ †Department of Gastroenterology and Hepatology, Academic Medical Centre, Amsterdam, The Netherlands \\ $\S$ Department of paediatric Surgery, Emma Children's Hospital, Amsterdam, The Netherlands \\ $\uparrow$ Chaire de Biologie, Conservatoire national des arts et métiers, Paris, France
}

\begin{abstract}
Background Disturbance in fluid secretion, driven by chloride secretion, might play a role in constipation. However, disturbed chloride secretion in those patients has yet to be evaluated. Therefore, the aim of this study was to compare chloride secretion in rectal biopsies of children with functional constipation (FC) to those without constipation. Methods To measure changes in short circuit current $\left(I_{s c}\right.$ in $\left.\mu \mathrm{A} \mathrm{cm}^{-2}\right)$ reflecting chloride secretion, intestinal biopsies from children with constipation, to either exclude or diagnose Hirschsprung's disease, and from children without constipation (controls) undergoing colonoscopy for screening of familial adenomatous polyposis, juvenile polyps or inflammatory bowel disease (IBD), were compared and studied in Ussing chambers. Following electrogenic sodium absorption blockade by amiloride, chloride secretory responses to calcium-linked (histamine, carbachol) and cAMP-linked (IBMX/forskolin) secretagogues were assessed. Key Results Ninety-six patients (46 FC) participated; nine FC patients ( $n=1$ congenital syndrome and $n=8$ technical problems) and 13 controls $(n=6$ $I B D ; n=7$ technical problems) were excluded. No significant difference was found in mean $( \pm S E)$ basal chloride currents between children with FC and controls $(9.6 \pm 1.1$ vs $9.2 \pm 0.8 ; \quad P=0.75$, respectively). Responses to calcium-linked chloride secretagogues (histamine and carbachol) were significantly higher in
\end{abstract}

Address for Correspondence

Noor Bekkali, MD, PhD, Department of Paediatric Gastroenterology and Nutrition, Academic Medical Centre, Emma Children's Hospital, Office C2-312, Meibergdreef 9, 1105 AZ Amsterdam, The Netherlands.

Tel: +31 20 5662906; fax: +31 20 6917033;

e-mail: n.bekkali@amc.nl

Received: 2 February 2011

Accepted for publication: 23 May 2011 controls $\quad(33.0 \pm 3.0$ vs $24.5 \pm 2.3 ; \quad P=0.03$ and $33.6 \pm 3.4$ vs $26.4 \pm 2.7 ; P=0.05$ following histamine and carbachol, respectively). Conclusions \& Inferences Calcium-linked chloride secretion is disturbed in children with FC. Whether this defect occurs at the level of histamine receptors, components of receptor-linked signal transduction pathways or basolateral $\mathrm{Ca}^{2+}$-sensitive $\mathrm{K}^{+}$channels enhancing the electrical driving force for apical chloride secretion, remains to be explored.

Keywords Children, chloride secretion, constipation, Ussing chamber.

Abbreviations: CFTR, cystic fibrosis transmembrane conductance regulator; FC, functional constipation.

\section{INTRODUCTION}

The intestinal epithelium has important ion transport capacity with chloride as the predominant electrolyte driving fluid secretion in the colon. ${ }^{1}$ The intestine and the organs draining into it, secrete approximately $8 \mathrm{~L}$ of fluid per day of which only $200 \mathrm{~mL}$ leaves the body within the stool. ${ }^{2,3}$ It is evident that pathological consequences will follow when chloride secretion increased or reduced as occurs in secretory diarrhea or cystic fibrosis, respectively., ${ }^{4,5}$

Two major proteins required for active chloride secretion are the $\mathrm{Na} / \mathrm{K} / 2 \mathrm{Cl}$ co-transporter (NKCC1) for chloride import and the cystic fibrosis transmembrane conductance regulator (CFTR) for chloride export, both located mainly in the crypts. ${ }^{6}$ In cystic fibrosis, many newborns present with meconiumileus, where thickened, dehydrated intestinal secretions cause intestinal obstruction shortly after birth. Therefore, disturbance in fluid secretion might also play a role in constipation. ${ }^{1}$ 
Chloride secretion stimulators act as selective chloride channel activators in the apical membrane of the gastrointestinal (GI) epithelium increasing intestinal chloride secretion and thereby intraluminal fluid collection in the gut, such as lubiprostone. ${ }^{7}$ Just recently, our group showed that lubiprostone stimulates chloride secretion by activation of the CFTR channel rather than by the earlier described ClC-2 channel. ${ }^{7-9}$ Interestingly, in adults with constipation, those stimulators were found to be efficient in increasing defecation frequency and in softening stools. ${ }^{10-12}$ However, a disturbance in gut CFTR expression or activation in patients with constipation remains to be evaluated, e.g., by monitoring

Although Ussing chambers are widely used for the characterization of GI ion transport in animal models, studies in human tissue have been fairly limited due to the scarce availability of adequately sized samples. ${ }^{7,13,14}$ In recent years, miniaturized container inserts which enclose smaller biopsy specimens and low volume Ussing chambers, have been developed to facilitate studies in human tissue. ${ }^{15,16}$ In this study, using such a miniaturized Ussing chamber system, we evaluated changes in chloride currents (as a measure for chloride secretion) ex vivo, in the rectal biopsies of children with functional constipation (FC) or controls following stimulation with secretagogues, as well as expression of CFTR in those biopsies.

\section{METHODS}

\section{Patients and biopsies}

Between April 2006 and June 2009 children with FC according to the Rome III criteria, who were resistant to laxative therapy and were undergoing rectal suction biopsies to diagnose or to exclude Hirschsprung's disease participated into the study. ${ }^{17,18}$ Two suspected for Hirschsprung's disease were consecutively taken upon endoscopy using a biopsy forceps with diameter $3.7 \mathrm{~mm}$ (Olympus, Zoetermeer, The Netherlands). Two biopsies of children without constipation, undergoing colonoscopy, to screen for familial adenomatous polyposis, to remove juvenile polyps or to screen for inflammatory bowel disease (IBD), were control biopsies. Biopsies of children with proven IBD or congenital defecation disorders (Hirschsprung's disease) were excluded from analysis.

\section{Ussing chambers protocol}

The colonic tissue obtained was transferred to ice-cold isotonic medium composed of $136.9 \mathrm{~mm} \mathrm{NaCl}, 2.7 \mathrm{~mm} \mathrm{KCL}, 0.9 \mathrm{~mm}$ $\mathrm{CaCL}_{2} 2 \mathrm{H}_{2} \mathrm{O}, 0.5 \mathrm{~mm} \mathrm{Na}_{2} \mathrm{HPO}_{4} \cdot 12 \mathrm{H}_{2} \mathrm{O}$, and $1.5 \mathrm{~mm} \mathrm{KH}_{2} \mathrm{PO}_{4}, \mathrm{pH}$ transepithelial chloride secretion in Ussing chambers. biopsies (up to $10-20 \mathrm{~cm}$ from the anal sphincter) of each patient

7.4. Then, the tissue was mounted in modified Ussing chambers (window area $0.025 \mathrm{~cm}^{2}$ ). The tissue was short-circuited using a dual voltage clamp (WPI, Berlin, Germany) and transepithelial current changes in response to secretagogues added to the bath were recorded ex vivo using Powerlab (AD Instruments, Spechbach, Germany).

Two biopsy specimens per patient were used for Ussing chambers experiments. The bath solution was a modified Meyler buffer composed of $105 \mathrm{~mm} \mathrm{NaCl}, 4.7 \mathrm{~mm} \mathrm{KCL}, 1.3 \mathrm{~mm} \mathrm{CaCL}_{2} \cdot 2$ $\mathrm{H}_{2} \mathrm{O}, 1.0 \mathrm{~mm} \mathrm{MgCL}_{2} \cdot 6 \mathrm{H}_{2} \mathrm{O}, 20.0 \mathrm{~mm} \mathrm{NaHCO}_{3}, 0.4 \mathrm{~mm} \mathrm{NaH}$ $\mathrm{PO}_{4} \cdot \mathrm{H}_{2} \mathrm{O}, 0.3 \mathrm{~mm} \mathrm{Na} 2 \mathrm{HPO}_{4} \cdot 2 \mathrm{H}_{2} \mathrm{O}, 10.0 \mathrm{~mm}$ HEPES, pH 7.4. The tissue was kept at $37^{\circ} \mathrm{C}$ using hot water jackets. Carbogen $\left(95 \% \mathrm{O}_{2} / 5 \% \mathrm{CO}_{2}\right)$ was constantly perfused through the chambers to oxygenate the tissue. After mounting the tissue, indomethacin was added to the bath to reduce the endogenous production of prostaglandins. Thereafter, biopsy specimens were allowed to equilibrate for $20 \mathrm{~min}$ to achieve stable measurements, after which experimental treatments were applied.

As depicted in Fig. 1, first, amiloride $(10 \mu \mathrm{M})$ was added to the mucosal side of the tissue to inhibit the contribution of epithelial $\mathrm{Na}^{+}$channels $(\mathrm{ENaC})$ to the current. The amiloride-sensitive current $\left(\Delta I_{\mathrm{sc}}\right)$ was defined as the difference between baseline $I_{\mathrm{sc}}$ before and after addition of amiloride. After $10 \mathrm{~min}$, the calciumlinked secretagogue histamine $(50 \mu \mathrm{M})$ was added to the serosal side (S). Then, after reaching stable currents ( 10 $\mathrm{min})$, another calcium-linked secretagogue, carbachol $(200 \mu \mathrm{M})$ was added to $\mathrm{S}$. Finally, after a new steady state was reached (ca. $10 \mathrm{~min}$ ), a cocktail of cAMP-linked agonists, forskolin $(10 \mu \mathrm{M})$, and IBMX $(0.1 \mathrm{~mm})$ was added to $\mathrm{S}$.

\section{Mechanisms of action of the secretagogues in human colon}

Histamine and carbachol stimulate chloride secretion mainly through activation of calcium-dependent $\mathrm{K}^{+}$channels (presumably of the KCa3.1/SK4 type) in the basolateral membrane. ${ }^{19,20}$ The resulting membrane hyperpolarization increases the electrochemical driving force for $\mathrm{Cl}^{-}$exit through partially open CFTR channels in the apical membrane. Forskolin stimulates chloride secretion through adenylylcyclase activation and cAMP formation. Cyclic AMP, through activation of cAMP-dependent protein kinase, phosphorylates and activates apical CFTR $\mathrm{Cl}^{-}$channels and basolateral $\mathrm{K}^{+}$channels (presumably KV7.1/KCNQ1). ${ }^{19,20}$ IBMX is a phosphodiesterase (PDE) inhibitor which indirectly augments cAMP levels. All secretagogues result in stimulation of chloride secretion with subsequent increase in $I_{\mathrm{sc}}$. The $\Delta I_{\mathrm{sc}}$ was measured as the difference between baseline $I_{\mathrm{sc}}$ (before addition of the secretagogues) and the peak level of the $I_{\mathrm{sc}}$ after addition of the secretagogues.

\section{Immunocytochemistry and confocal microscopy}

Cryo-sections $(8 \mu \mathrm{m})$ of human rectal biopsies were stored at $-80^{\circ} \mathrm{C}$ and analyzed according to the previously described protocol by Broere et al., where sections were fixated for $10 \mathrm{~min}$ with $4 \%$ paraformaldehyde and for $20 \mathrm{~min}$ in methanol, followed by washing in $0.5 \%$ protifar (low-fat babymilk) and $0.15 \%$ glycine in PBS, $\left(=\mathrm{PBS}^{+}\right){ }^{21}$ Then, sections were incubated for $90 \mathrm{~min}$ in $\mathrm{PBS}^{+}$containing anti-CFTR monoclonal antibody $(528,1: 50)$ kindly donated by Prof. J.R. Riordan, University of North Carolina

\begin{tabular}{|c|c|c|c|c|}
\hline$t=-0$ & $t=20 \mathrm{~min}$ & $t=30 \mathrm{~min}$ & $t=40 \mathrm{~min}$ & $\begin{array}{l}t=50 \mathrm{~min} \\
\mathrm{l}\end{array}$ \\
\hline $\begin{array}{l}\text { Mount the tissue } \\
\text { Add indomethacin }\end{array}$ & $\begin{array}{l}\text { Record baseline Isc values } \\
\text { Add amiloride }\end{array}$ & $\begin{array}{l}\text { Record Isc values } \\
\text { Add histamine }\end{array}$ & $\begin{array}{l}\text { Record Isc values } \\
\text { Add carbachol }\end{array}$ & $\begin{array}{l}\text { Record Isc values } \\
\text { Add forskolin/IBMX }\end{array}$ \\
\hline
\end{tabular}


at Chapel Hill). ${ }^{14}$ Subsequently, sections were washed with $\mathrm{PBS}^{+}$, incubated for $60 \mathrm{~min}$ with Cy3-labeled anti-mouse IgG $(1: 100$, Jackson Immunoresearch Laboratory, West Grove, PA, USA)and mounted with Vectashield (Vector Laboratories Inc., Burlingame, CA, USA). Immunofluorescence micrographs were captured using a ZeissLSM510 confocal microscope equipped with a 25 milliwatt argonlaser. Fluorescence emission after excitation $(488 \mathrm{~nm}$ for CFTR) was detected using $10 \times / 0.3$ or $40 \times / 1.3$ numerical aperture oil immersion lenses, a dichroic beam splitter reflecting 488-nm excitation light, and a 505-530 bandpass emission filter. The images were scanned using a $75-\mu \mathrm{m}$ pinhole.

For (semi)quantification of signal from colonic crypts, images from longitudinal sections at Z-steps of $0.5 \mu \mathrm{m}$ were analyzed by determining total background-subtracted fluorescent signal using Ks400 ZeIss software. The same threshold was utilized for all images from one slide. Three individual crypts of each biopsy were analyzed in a blinded fashion.

\section{Medical ethical committee}

All parents and children aged $>12$ years gave written consent. This study was approved by the medical ethical committee of the Academic Medical Centre of Amsterdam.

\section{Statistical analysis}

A sample size of 37 samples from each group was required to achieve $80 \%$ power at a significance level of 0.05 to detect a difference in means of twice the current change between the two groups. Such a difference was anticipated on the basis of earlier data by Bijlsma et al. ${ }^{22}$ The latter study performed in adult FC patients showed preliminary evidence for a dramatically reduced response to the secretagogues histamine and carbachol (by $>85 \%$ ) in the epithelium of constipated patients. Baseline characteristics and difference in change of current between constipated and control tissue, were described and analyzed using the Student's $t$-test (spss version 14.0 statistical software, Chicago, IL, USA). A $P$-value $=0.05$ (two-tailed) was considered statistically significant.

\section{RESULTS}

\section{Baseline characteristics of participating patients}

A total of 46 children with FC ( 25 male) with mean constipation duration of $3.6 \pm 3.1$ years and 50 (23 male) controls participated (Table 1, Fig. 2). Eighteen patients (biopsies) were excluded in the FC group, one set of biopsies was provided from a patient with a congenital disease (trisomy 12) and eight other experiments were excluded due to technical problems with the equipment (see also Fig. 2). A total of 13 controls were excluded, six patients had IBD and in seven patients the experiments could not be conducted due to technical problems. Equipment problems occurred several times (in 15 patients, in six overlapping sessions of experiments). These problems were diverse, including electrical problems arising in the hospital, inadequate temperature of the water jackets or computer system failure.
Table 1 Baseline characteristics of the controls and patients with functional constipation

\begin{tabular}{lclc}
\hline & $\begin{array}{l}\text { Controls } \\
(n=37)\end{array}$ & $\begin{array}{l}\text { Constipation } \\
(n=37)\end{array}$ & $P$-value \\
\hline $\begin{array}{c}\text { Mean } \pm \text { SE age (years) } \\
\begin{array}{c}\text { Duration constipation } \\
\text { symptoms (years) }\end{array}\end{array}$ & $10.7 \pm 0.6$ & $6.3 \pm 0.6$ & $<0.001$ \\
$\begin{array}{c}\text { Mean } \pm \text { SE defecation } \\
\text { frequency/week }\end{array}$ & $10.0 \pm 7.2$ & $0.7 \pm 1.2$ & $<0.001$ \\
$\begin{array}{c}\text { Mean } \pm \text { SE fecal } \\
\text { incontinence } \\
\text { frequency/week }\end{array}$ & $0.3 \pm 0.1$ & $8.2 \pm 1.5$ & $<0.001$ \\
$\begin{array}{c}\text { Number of patients } \\
\text { with hard stool } \\
\text { consistency }\end{array}$ & 2 & 25 & $<0.001$ \\
\hline
\end{tabular}

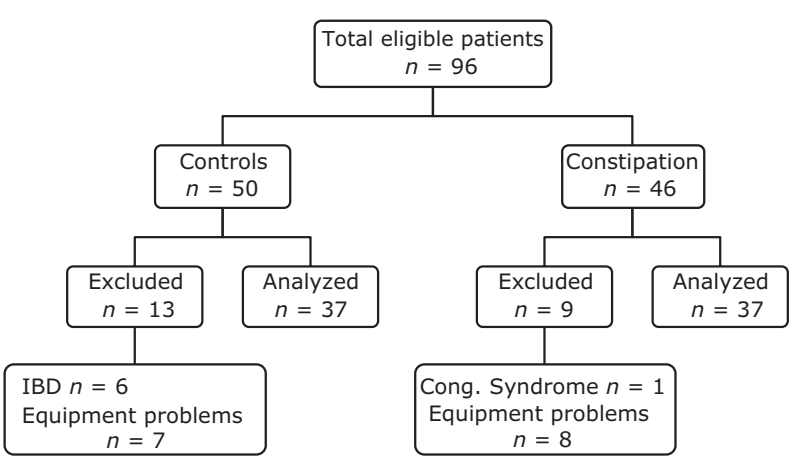

Figure 2 Flow chart of the participating patients.

\section{Basal properties of human rectal mucosa}

Under basal conditions, after 20 min stabilization in the Ussing chamber, basal $I_{\mathrm{sc}}$ of the control tissue biopsies was $9.2 \pm 0.8 \mu \mathrm{A} \mathrm{cm}^{-2}$ compared with $9.6 \pm 1.1 \mu \mathrm{A} \mathrm{cm}^{-2}$ in the FC patients; $P=0.75$.

\section{Effect of amiloride and correlation with defecation frequency}

Amiloride caused a change in current of $-11.8 \pm$ $1.0 \mu \mathrm{A} \mathrm{cm}^{-2}$ in $\mathrm{FC}$ biopsies compared with $-14.7 \pm$ $2.2 \mu \mathrm{A} \mathrm{cm}^{-2}$ in control biopsies $(P=0.25)$. In constipated and control biopsies, no correlation was found between amiloride-induced current changes and defecation frequency per week, $(r=-0.01 ; P=0.95$ and $r=0.01$, respectively; $P=0.92$ ).

\section{Effect of secretagogues and correlation with defecation frequency}

As depicted in Table 2, carbachol induced a higher current change in controls but this difference did not reach statistical significance. However, if the working 


\begin{tabular}{lrlll}
\hline & $\begin{array}{l}\text { Controls } \\
(n=37)\end{array}$ & $\begin{array}{l}\text { Constipation } \\
(n=37)\end{array}$ & $\begin{array}{l}P \text {-value } \\
\text { two-tailed }\end{array}$ & $\begin{array}{l}P \text {-value } \\
\text { one-tailed }\end{array}$ \\
\hline Amiloride $(\mathrm{M}, 10 \mu \mathrm{M})$ & $-14.7 \pm 2.2$ & $-11.8 \pm 7.0$ & 0.25 & - \\
Histamine $(\mathrm{S}, 50 \mu \mathrm{M})$ & $33.0 \pm 3.0$ & $24.5 \pm 2.3$ & 0.03 & - \\
Carbachol $(\mathrm{S}, 200 \mu \mathrm{M})$ & $33.6 \pm 3.4$ & $26.4 \pm 2.7$ & 0.10 & 0.05 \\
Forskolin $(\mathrm{S}, 10 \mu \mathrm{M})+$ & $15.1 \pm 2.2$ & $15.4 \pm 2.4$ & 0.94 & - \\
IBMX $(\mathrm{S}, 200 \mu \mathrm{M})$ & & & & \\
\hline
\end{tabular}

Table 2 Mean $( \pm \mathrm{SE})$ change in current $\left(\Delta I_{\mathrm{sc}}\right.$ : $\mu \mathrm{A} \mathrm{cm}^{-2}$ ) after adding amiloride, histamine, carbachol, and forskolin/IBMX to the mucosal (M) or serosal (S) bath in the Ussing chamber

hypothesis is narrowed down to the question whether carabachol-induced difference in current in FC patients is lower than that in controls, which is allowed based on the previously described results in adults by Bijlsma, one-tailed testing shows a statistically significant $P$-value of $0.05 .^{22}$

Histamine caused a current change of $24.5 \pm$ $2.3 \mu \mathrm{A} \mathrm{cm}^{-2}$ in FC compared with $33.0 \pm 3.0 \mu \mathrm{A} \mathrm{cm}{ }^{-2}$ in controls $(P=0.028)$. In controls, a correlation was found between the currents, following stimulation with histamine $(r=0.4 ; \quad P=0.001)$ and carbachol $(r=0.5 ; \quad P<0.001)$, and defecation frequency. No correlation was found between defecation frequency and currents following IBMX-forskolin $(r=-0.2$; $P=0.24)$ in controls. In constipated biopsies no such correlations were found with any secretagogue.

\section{Correlation of the current responses with age}

No correlation was found between age and amilorideinduced current changes $(r=-0.07 ; P=0.43)$. Likewise for the secretagogues histamine $(r=-0.02 ; P=0.80)$, carbachol $(r=-0.07 ; \quad P=0.44)$, and IBMX-forskolin $(r=-0.01 ; P=0.9)$, no correlation was found with age.

\section{Immunocytochemistry}

As shown in Figs 3 and 4, CFTR immunostaining was confined almost exclusively to the apical membrane of colonic crypt cells, in agreement with a previous immunolabeling study reporting the absence of apical staining by the same monoclonal anti-CFTR antibody in rectal biopsies from CF patients. ${ }^{14}$ Quantification of the immunofluorescence-staining intensity of the CFTR channel protein did not reveal a significant difference between control and FC biopsies indicating that the expression and distribution of CFTR protein was not affected significantly by the FC condition.

\section{DISCUSSION}

In this study, we showed that calcium-linked chloride secretion in the rectum is disturbed in constipated children when compared to controls. Likewise, a

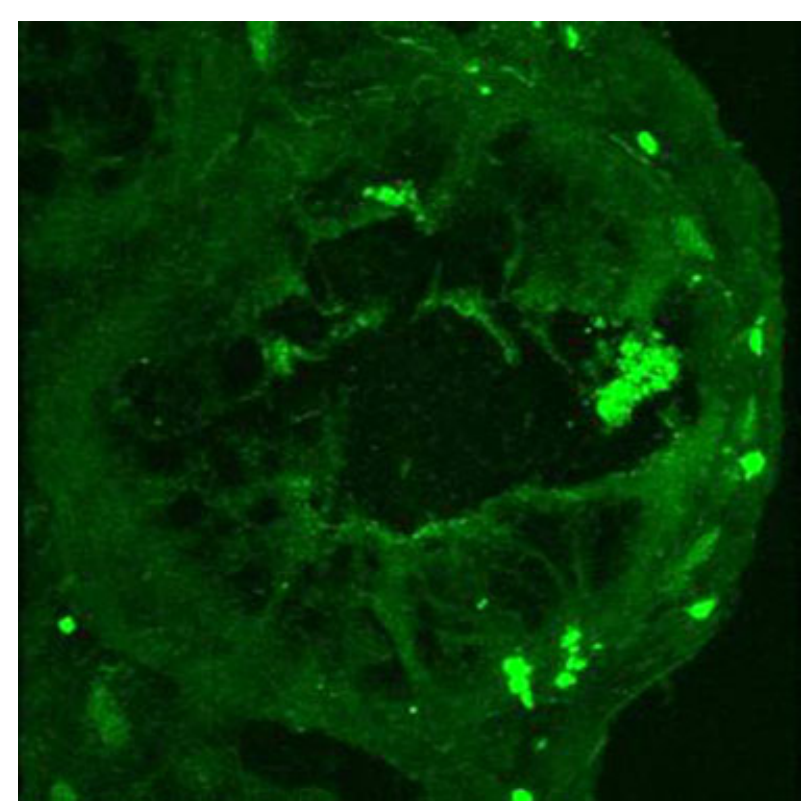

Figure 3 CFTR immunostaining of biopsies from controls.

positive correlation was found between calcium-linked chloride secretion, as induced by histamine and carbachol, and defecation frequency in control biopsies but not in biopsies from constipated patients (FC). However, neither the amount of CFTR chloride channel protein nor its apical localization in the colonic crypts was affected by the FC condition.

To our knowledge this is the first study evaluating chloride secretion in tissue of constipated children. Constipated children had overall disturbed calciumlinked chloride secretion but statistical significance compared to non-constipated children was only reached following stimulation with histamine. Because the measurements are performed ex vivo and the secretagogues are added exogenously, the reduction in transepithelial chloride secretion in response to histamine in the FC group cannot be explained by possible differences in local histamine levels. Histamine was only included in our protocol for its potent calcium-linked secretagogue effect. ${ }^{23}$ However, just recently a correlation between mast cells and nerve fibers in rectal mucosa was found in children with 


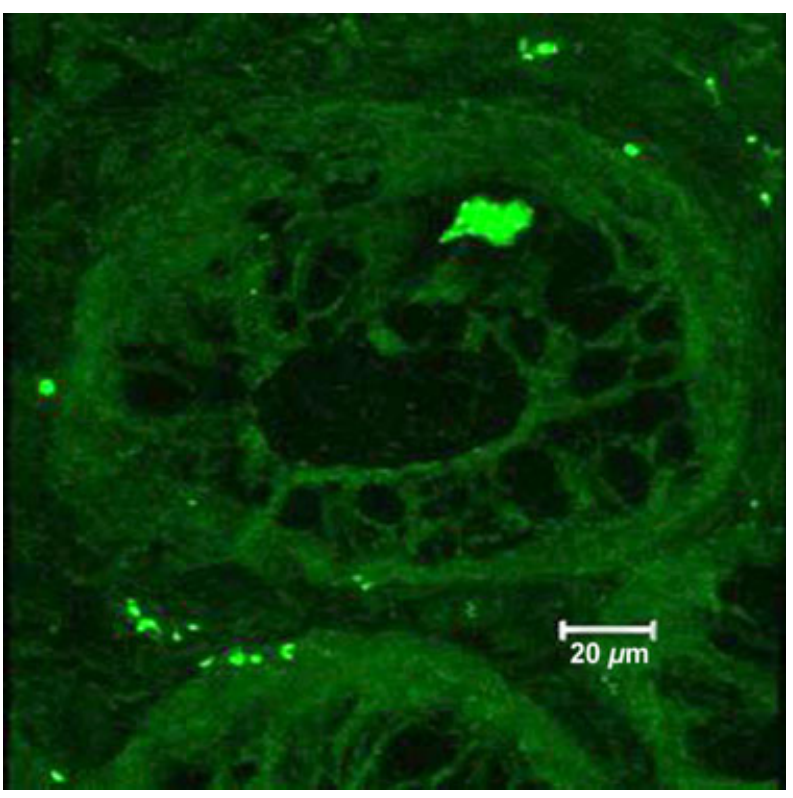

Figure 4 CFTR immunostaining of biopsies from constipated children.

chronic constipation. ${ }^{24}$ In the latter study, constipated children showed an increase in mast cell area. Considering the potential histamine release by mast cells, exogenous histamine might not have reached its optimal effect due to desensitization of the histamine 1 receptor in constipated children from our study. ${ }^{25,26}$ Given the latter, further research to elucidate the possible role of mast cells and their mediators in constipated children is justified.

Considering the diminished chloride secretory response to calcium-linked secretagogues but not to cAMP-linked secretagogues (forskolin-IBMX) in constipated children, and the positive correlation of defecation frequency with calcium dependent secretagogues in controls, the disturbance in chloride secretion in the FC group is most plausibly due to a defect in intracellular calcium signaling. Whether this defect occurs at the level of the histamine receptor, components of the receptor-linked signal transduction pathway (e.g., phospholipase C, inositol 1,4,5-trisphosphate-triggered calcium release), or basolateral $\mathrm{Ca}^{2+}$ sensitive $\mathrm{K}^{+}$channels (presumably SK4) that enhance the electrical driving force for apical chloride secretion through the CFTR $\mathrm{Cl}^{-}$channel, remains to be explored. The transient character of the current response to calcium-linked secretagogues, closely following the transient increase in intracellular $\mathrm{Ca}^{2+}$, might suggest that in constipated children an enhanced storage or buffering capacity of intracellular $\mathrm{Ca}^{2+}$ rather than a reduced mobilization could be responsible for the difference in current changes. This is, however, unlikely as we measured the maximal change in current after secretagogues addition which occurred within one minute, i.e., before the reuptake of calcium into cellular reservoirs begins. Therefore, the CFTR channel activator lubiprostone, which does not to elicit a rise in cellular $\mathrm{Ca}^{2+}$ levels, would still be an obvious candidate to treat children with constipation. ${ }^{7}$ The latter is even more important as we found a positive correlation of chloride secretion with defecation frequency in controls.

In contrast to the findings with $\mathrm{Ca}^{2+}$-linked secretagogues, the chloride current response to cAMP-linked agonists (IBMX-forskolin), was not different between controls and constipated children. Moreover, the expression level and apical distribution of the CFTR protein in the colonic crypts was also not affected by FC. Both findings strongly indicate that the components of the cAMP signalling pathway, i.e., cAMPdependent protein kinase, apical CFTR chloride channels, basolateral $\mathrm{K}^{+}$channels (KCNQ1), and the $\mathrm{NaKCl} 2$ co-transporter (NKCC1) were functioning normally in the colon of the constipated children, and stress the specificity of the defect in components of the calcium signalling pathway that are not shared with the cAMP pathway.

In adults, drugs stimulating chloride secretion are already successfully applied in treating FC and IBSC. ${ }^{10,27}$ For children, no data are published concerning treatment with those agents. Childhood FC treatment encloses a combination of behavioral and medical therapy. Polyethylene glycol (PEG) is the first line drug used in these children and aims to soften the stools, thereby contributing to a break-through of the vicious circle of defecation avoidance caused by pain during defecation. ${ }^{28}$ As only $60 \%$ of constipated children accomplish successful treatment with PEG, we recommend conducting randomized controlled trials to assess the effect of PEG vs chloride secretion stimulators such as lubiprostone or linaclotide. ${ }^{29}$

In conclusion, disturbed chloride secretion is found in constipated children following stimulation with histamine. Furthermore, calcium-dependent chloride secretion was positively correlated with defecation frequency in control biopsies. Given these results, it is recommendable to conduct trials to investigate the role of drugs stimulation chloride secretion in constipated children.

\section{ACKNOWLEDGMENTS}

We wish to thank Alice Bot and Flore Dossou for their advice and training in using the Ussing chamber technique, and Huub Jorna for conducting the immunocytochemical experiments. 


\section{AUTHOR CONTRIBUTION}

HRJ, RvdW and JATA helped in designing the study as well as in co-writing the article; AvdS contributed essential reagents or tools; PB helped in analyzing the study; JFD helped designing the study; MAB was responsible for designing the study, analyzing the data as well as contributing essential reagents; NB was responsible for all aspects of the study.

\section{REFERENCES}

1 Barrett KE, Keely SJ. Chloride secretion by the intestinal epithelium: molecular basis and regulatory aspects. Annu Rev Physiol 2000; 62: 535-72.

2 Montrose MH, Keely SJ, Barrett KE. Electrolyte secretion and absorption: small intestine and colon. In: Yamada T, ed. Textbook of Gastroenterology, 4th edn. Philadelphia, PA: Lippincott Williams \& Wilkins, 2003.

3 Ewe K. Intestinal transport in constipation and diarrhoea. Pharmacology 1988; 36(Suppl. 1): 73-84.

4 Wilschanski M, Durie PR. Patterns of GI disease in adulthood associated with mutations in the CFTR gene. Gut 2007; 56: 1153-63.

5 Field M. Mechanisms of action of cholera and Escherichia coli enterotoxins. Am J Clin Nutr 1979; 32: 189 96.

6 Strong TV, Boehm K, Collins FS. Localization of cystic fibrosis transmembrane conductance regulator mRNA in the human gastrointestinal tract by in situ hybridization. I Clin Invest 1994; 93: 347-54.

7 Bijvelds MJ, Bot AG, Escher JC et al. Activation of intestinal $\mathrm{Cl}^{-}$secretion by lubiprostone requires the cystic fibrosis transmembrane conductance regulator. Gastroenterology 2009; 137: 976-85.

8 Cuppoletti J, Tewari KP, Sherry AM et al. Sites of protein kinase A activation of the human $\mathrm{ClC}-2 \mathrm{Cl}^{-}$channel. J Biol Chem 2004; 279: 21849-56.

9 Cuppoletti J, Malinowska DH, Tewari KP et al. SPI-0211 activates T84 cell chloride transport and recombinant human $\mathrm{ClC}-2$ chloride currents. Am I Physiol Cell Physiol 2004; 287: C1173-83.

10 Johanson JF, Morton D, Geenen J et al. Multicenter, 4-week, doubleblind, randomized, placebo-controlled trial of lubiprostone, a locally-acting type- 2 chloride channel activator, in patients with chronic constipation. Am I Gastroenterol 2008; 103: 170-7.

11 Johanson JF, Ueno R. Lubiprostone. A locally acting chloride channel activator, in adult patients with chronic constipation: a double-blind, placebocontrolled, dose-ranging study to evaluate efficacy and safety. Aliment Pharmacol Ther 2007; 25: 1351-61.

12 Andresen V, Camilleri M, Busciglio IA et al. Effect of 5 days linaclotide on transit and bowel function in females with constipation-predominant irritable bowel syndrome. Gastroenterology 2007; 133: 761-8.

13 de Jonge HR, Ballmann M, Veeze $H$ et al. Ex vivo CF diagnosis by intestinal current measurements (ICM) in small aperture, circulating Ussing chambers. J Cyst Fibros 2004; 3(Suppl. 2): 159-63.

14 Mall M, Kreda SM, Mengos A et al. The DeltaF508 mutation results in loss of CFTR function and mature protein in native human colon. Gastroenterology 2004; 126: 32-41.

15 Stockmann M, Gitter AH, Sorgenfrei $\mathrm{D}$ et al. Low edge damage container insert that adjusts intestinal forceps biopsies into Ussing chamber systems. Pflugers Arch 1999; 438: 10712.

16 Mall M, Wissner A, Seydewitz $\mathrm{HH}$ et al. Defective cholinergic $\mathrm{Cl}^{-}$ secretion and detection of $\mathrm{K}^{+}$secretion in rectal biopsies from cystic fibrosis patients. Am I Physiol Gastrointest Liver Physiol 2000; 278: G617-24.

17 Benninga M, Candy DC, Catto-Smith AG et al. The Paris Consensus on Childhood Constipation Terminology (PACCT) Group. I Pediatr Gastroenterol Nutr 2005; 40: 273-5.

18 Rasquin A, Di Lorenzo C, Forbes D et al. Childhood functional gastrointestinal disorders: child/adolescent. Gastroenterology 2006; 130: 1527-37.

19 Matos JE, Sausbier M, Beranek G et al. Role of cholinergic-activated KCa1.1 (BK), KCa3.1 (SK4) and KV7.1 (KCNQ1) channels in mouse colonic $\mathrm{Cl}^{-}$secretion. Acta Physiol (Oxf) 2007; 189: 251-8.

20 Flores CA, Melvin JE, Figueroa CD et al. Abolition of $\mathrm{Ca}^{+}$-mediated intestinal anion secretion and increased stool dehydration in mice lacking the intermediate conductance $\mathrm{Ca} 2^{+}$-dependent $\mathrm{K}^{+}$channel Kcnn4. I Physiol 2007; 583: 705-17.
21 Broere N, Hillesheim J, Tuo B et al. Cystic fibrosis transmembrane conductance regulator activation is reduced in the small intestine of $\mathrm{Na}^{+}$/ $\mathrm{H}^{+}$exchanger 3 regulatory factor 1 (NHERF-1) but Not NHERF-2deficient mice. J BiolChem 2007; 282: 37575-84.

22 Bijlsma PB, Hommes D, Erkelens W et al. Impaired response of rectal epithelium to secretory stimuli in patients with obstipation; a preliminary study. I Physiol Biochem 2001; 57: 125

23 Bijlsma PB, Backhaus B, Weidenhiller $M$ et al. Food allergy diagnosis by detection of antigen-induced electrophysiological changes and histamine release in human intestinal biopsies during mucosa-oxygenation. Inflamm Res 2004; 53(Suppl. 1): S29-30.

24 Borrelli O, Barbara G, Di Nardo G et al. Neuroimmune interaction and anorectal motility in children with food allergy-related chronic constipation. Am I Gastroenterol 2009; 104: 454-63.

25 Schultheiss G, Hennig B, Schunack $\mathrm{W}$ et al. Histamine-induced ion secretion across rat distal colon: involvement of histamine $\mathrm{H} 1$ and $\mathrm{H} 2$ receptors. Eur J Pharmacol 2006; 546: 161-70.

26 McCreath G, Hall IP, Hill SJ. Agonistinduced desensitization of histamine $\mathrm{H} 1$ receptor-mediated inositolphospholipid hydrolysis in human umbilical vein endothelial cells. $B r \quad J$ Pharmacol 1994; 113: 823-30.

27 Johanson JF, Drossman DA, Panas R et al. Clinical trial: phase 2 study of lubiprostone for irritable bowel syndrome with constipation. Aliment Pharmacol Ther 2008; 27: 685-96.

28 Schiller LR, Emmett M, Santa Ana CA et al. Osmotic effects of polyethylene glycol. Gastroenterology 1988; 94: 933-41.

29 Voskuijl W, de Lorijn F, Verwijs W et al. PEG 3350 (Transipeg) versus lactulose in the treatment of childhood functional constipation: a double blind, randomised, controlled, multicentre trial. Gut 2004; 53: 1590-4. 